\title{
Impact of unemployment and income on entrepreneurship in post-apartheid South Africa: 1994-2015
}

\begin{tabular}{|c|c|}
\hline \multicolumn{2}{|c|}{$\begin{array}{l}\text { Authors: } \\
\text { Darma Mahadea }{ }^{1} \\
\text { Irrshad Kaseeram }^{2}\end{array}$} \\
\hline \multicolumn{2}{|c|}{$\begin{array}{l}\text { Affiliations: } \\
{ }^{1} \text { School of Accounting, } \\
\text { Economics and Finance and } \\
\text { Economics, University of } \\
\text { KwaZulu-Natal, South Africa }\end{array}$} \\
\hline \multicolumn{2}{|c|}{$\begin{array}{l}{ }^{2} \text { Department of Economics, } \\
\text { University of Zululand, } \\
\text { South Africa }\end{array}$} \\
\hline \multicolumn{2}{|c|}{$\begin{array}{l}\text { Corresponding author: } \\
\text { Darma Mahadea, } \\
\text { mahadead@ukzn.ac.za }\end{array}$} \\
\hline \multicolumn{2}{|c|}{$\begin{array}{l}\text { Dates: } \\
\text { Received: } 01 \text { Nov. } 2016 \\
\text { Accepted: } 06 \text { Dec. } 2017 \\
\text { Published: } 22 \text { Mar. } 2018\end{array}$} \\
\hline \multicolumn{2}{|c|}{$\begin{array}{l}\text { How to cite this article: } \\
\text { Mahadea, D. \& Kaseeram, I., } \\
2018, \text { 'Impact of } \\
\text { unemployment and income } \\
\text { on entrepreneurship in } \\
\text { post-apartheid South Africa: } \\
\text { 1994-2015', Southern African } \\
\text { Journal of Entrepreneurship } \\
\text { and Small Business } \\
\text { Management 10(1), a115. } \\
\text { https://doi.org/10.4102/ } \\
\text { sajesbm.v10i1.115 }\end{array}$} \\
\hline \multicolumn{2}{|c|}{$\begin{array}{l}\text { Copyright: } \\
\text { ( 2018. The Authors. } \\
\text { Licensee: AOSIS. This work } \\
\text { is licensed under the } \\
\text { Creative Commons } \\
\text { Attribution License. }\end{array}$} \\
\hline \multicolumn{2}{|l|}{ Read online: } \\
\hline 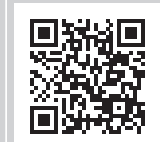 & $\begin{array}{l}\text { Scan this QR } \\
\text { code with your } \\
\text { smart phone or } \\
\text { mobile device } \\
\text { to read online. }\end{array}$ \\
\hline
\end{tabular}

Background: South Africa has made significant progress since the dawn of democracy in 1994. It registered positive economic growth rates and its real gross domestic product (GDP) per capita increased from R42 849 in 1994 to over R56 000 in 2015. However, employment growth lagged behind GDP growth, resulting in rising unemployment.

Aim and setting: Entrepreneurship brings together labour and capital in generating income, output and employment. According to South Africa's National Development Plan, employment growth would come mainly from small-firm entrepreneurship and economic growth. Accordingly, this article investigates the impact unemployment and per capita income have on early stage total entrepreneurship activity (TEA) in South Africa, using data covering the 1994-2015 period.

Methods: The methodology used is the dynamic least squares regression. The article tests the assertion that economic growth, proxied by real per capita GDP income, promotes entrepreneurship and that high unemployment forces necessity entrepreneurship.

Results: The regression results indicate that per capita real GDP, which increases with economic growth, has a highly significant, positive impact on entrepreneurial activity, while unemployment has a weaker effect. A $1 \%$ rise in real per capita GDP results in a $0.16 \%$ rise in TEA entrepreneurship, and a $1 \%$ rise in unemployment is associated with a $0.25 \%$ rise in TEA.

Conclusion: There seems to be a strong pull factor, from income growth to entrepreneurship and a reasonable push from unemployment to entrepreneurship, as individuals without employment are forced to self-employment as a necessity, survival mechanism. Overall, a longrun co-integrating relationship seems plausible between unemployment, income and entrepreneurship in South Africa.

\section{Introduction}

Entrepreneurship is currently the focus of policy interest globally. Against a backdrop of poverty, income inequality, and rising unemployment in South Africa, vigorous entrepreneurship, as partly manifested through the creation and expansion of small and medium enterprises (SMEs), is critical for economic development (Herbst \& Mills 2015; Herrington, Kew \& Kew 2015). Entrepreneurship brings labour and capital together, and it is the pathway to employment and economic growth.

South Africa has had a record of economic expansion since democracy in 1994. Accompanying this growth, employment increased by over $3.5 \mathrm{~m}$ during the past 20 years. However, more people enter the labour market each year in search of employment, resulting in a rise in the unemployment rate. If one includes the discouraged work effect (about 2.5 million individuals), then unemployment in South Africa was close to $34 \%$ in 2016, which is extremely high by global standards. Even using the narrow 'official' definition, the unemployment rate increased from $20 \%$ in 1994 to $23 \%$ in 2008 to over $26 \%$ in 2016; youth unemployment is shockingly higher at $53 \%$ in 2016 [South African Reserve Bank (SARB) 2016]. While in absolute terms employment increased with economic growth over time, more so for skilled labour, there has also been some job destruction with business closures (Johnson 2015; Kerr Winttenberg \& Arrow 2014).

The National Development Plan (NDP) envisages that, if unemployment is to fall to $14 \%$ by 2020 and $6 \%$ by 2030 , South Africa needs an average annual gross domestic product (GDP) growth of 5.4\%. It further suggests that entrepreneurship in the small-firm sector would be critical in 
generating growth in employment and income. The postapartheid government has put in place various strategies to enhance entrepreneurship and job creation. These include the growth, employment and redistribution strategy, National Empowerment Fund, Accelerated and Shared Growth Initiative of South Africa, the Small Enterprise Finance Agency, Youth Development Agency, NDP, and a new ministry for small business recently. Despite all these initiatives, South Africa's contemporary growth (Figure 1) and unemployment rates (Figure 2) are worryingly a development concern. Encouragingly, in September 2016, the SME Fund was launched to stimulate entrepreneurship. This is a CEO initiative, where a group of 90 business executives and leaders from the private sector in South Africa established a fund of R1.5b to boost SMEs and employment, together with the state.

There is an apparent 'tension' in the literature, where arguments have been put forward that entrepreneurship can be 'bad' for the economy due to overinvestment by entrepreneurs leading to business failures and other social costs (de Meza \& Webb 1987). The business demise argument is sensitive in the South African context, as vulnerable groups with a low asset base, for example, blacks and women, tend to lose the most from business failures. Yet, they are the most targeted groups by entrepreneurship promotion policies. However, the literature and empirical studies also suggest that promoting an entrepreneurship ecosystem spurs competition, innovation, employment, venture development and economic growth as well as reducing poverty (Herrington et al. 2015; Kantor 2017; Naude 2008; Nieman \& Nieuwenhuizen 2014; Urban 2013).

Following Schumpeter, entrepreneurship and economic growth are positively related; an increase in the number of entrepreneurs leads to an increase in economic growth and income, largely through their introductions of innovative technologies, products and services in existing and new ventures. New firms create additional business opportunities,

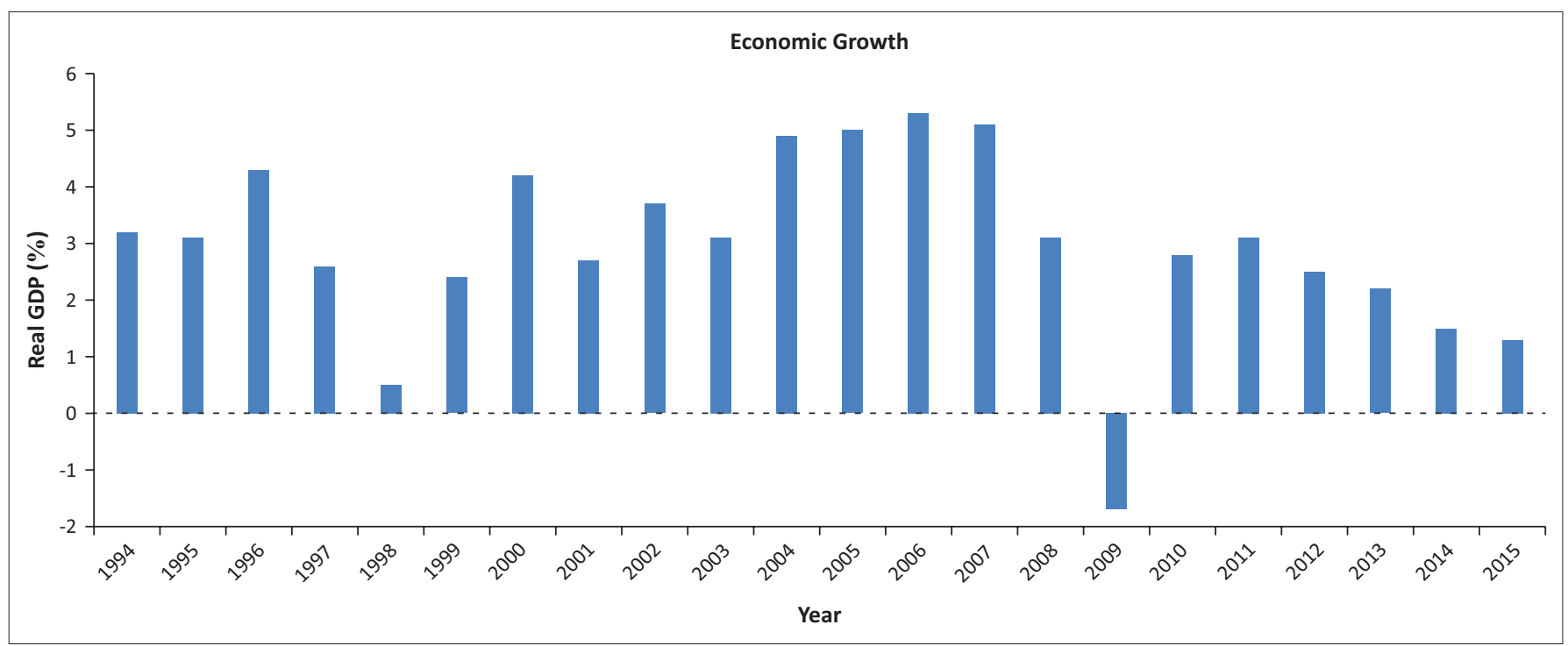

FIGURE 1: Economic growth in South Africa: 1994-2015.

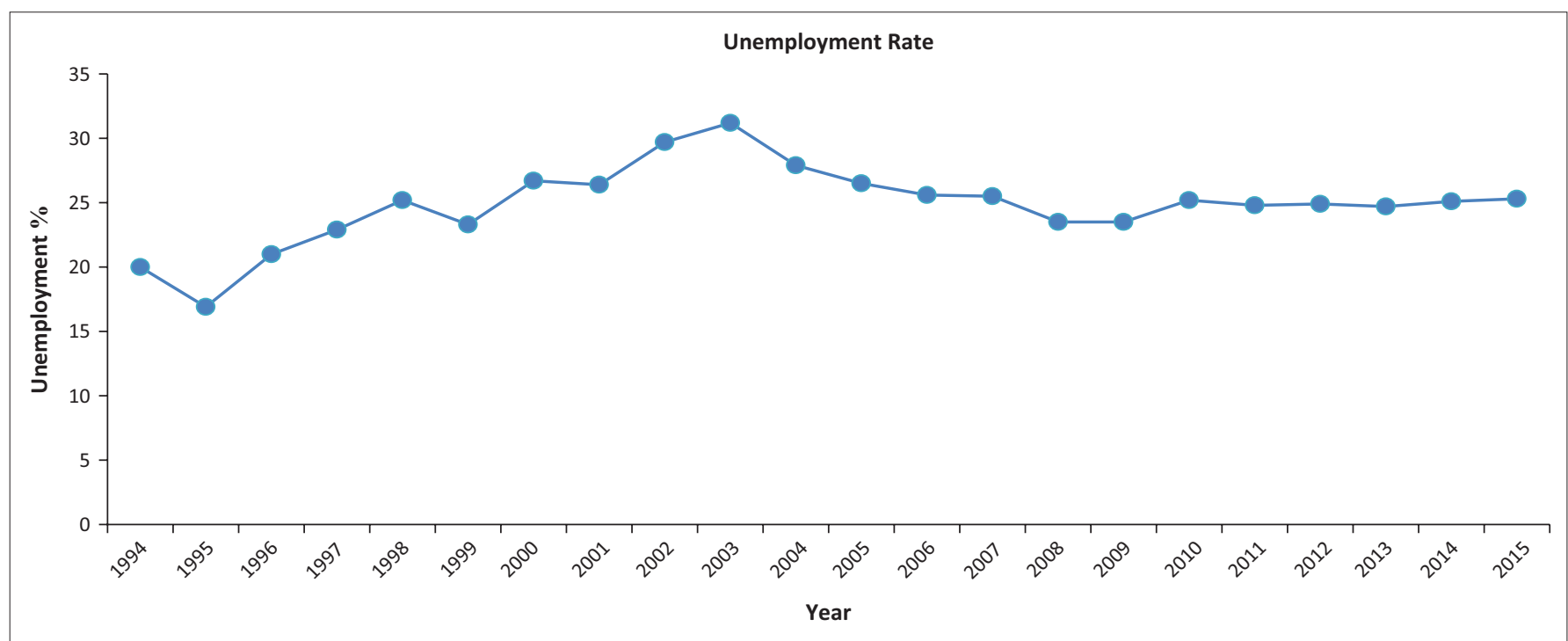

FIGURE 2: Unemployment rate in South Africa: 1994-2015. 
boost aggregate demand and generate new employment opportunities (Kritikos 2014). South Africa is critically in need of vigorous entrepreneurship to address the problems of poverty, income generation and slow economic growth as well as historical imbalances resulting from apartheid (Herbst \& Mills 2015). Accordingly, in light of these insights, this article seeks to assess whether a credible longrun cointegrating relationship exists between GDP income, entrepreneurship and unemployment in post-apartheid South Africa. The article consists of five sections; the first provides an overview of unemployment, economic growth and entrepreneurship. The second section briefly links entrepreneurship to economic growth via the neoclassical and endogenous growth models. The third section covers the research methodology, and the last two sections discuss the findings and policy directions regarding entrepreneurship.

\section{Unemployment, income and entrepreneurship in South Africa}

South Africa has registered positive economic growth since democracy in 1994, an average economic rate of 3.6\% during 1994-2012 and 5\% for a couple of years (Figure 1). With the positive economic growth rates, income has consistently increased. As a result, real GDP per capita has increased from R42 849 in 1994 to R55 508 in 2012 and to R56 169 in 2015 (SARB 2016). However, employment lagged behind economic growth during the same period. While unemployment decreased between 2004 and 2009, the trend is on the rise (Figure 2); unemployment increased from 20\% in 1994 to $26 \%$ in 2015 despite numerous policy interventions, of which SME entrepreneurship features prominently.

In South Africa, SMEs contribute over $40 \%$ towards the country's overall GDP and provide more than $50 \%$ of employment to labour (Kelly, Singer \& Herrington 2016; Parsons 2013). However, according to the Global Entrepreneurship Monitor (GEM) reports, South Africa, as an efficiency-driven economy similar to countries like Russia, Brazil, Mexico and Thailand, has a low level of total early stage entrepreneurship activity (TEA). Total entrepreneurship activity is the percentage of the adult population who are in the process of starting or have started a business that has been operational for at least 42 months. South Africa's TEA ranged from $9.4 \%$ in 2001 to $10.6 \%$ in 2013; the figure dropped to $6.97 \%$ in 2014, but increased to $9.2 \%$ in 2015 (Kelly et al. 2016).

An OECD (2017) report asserts that South Africa can unlock significant employment creation and business opportunities through aligning of skills acquisition with labour market needs, addressing skills development and investment for both workers and employers, through on-the-job learning; and policies facilitating the entry of migrants with soughtafter scarce skills. This article makes the conceptual argument that an economy that sets up the necessary infrastructure, skill set and investor-friendly policies will advance economic growth which, in turn, will promote small business development.

\section{Linking entrepreneurship to economic growth}

Within the tradition of the Austrian school of entrepreneurship, the entrepreneur is the alert individual who discovers new opportunities, acts on them and introduces change for profitable ends in a market that is never in equilibrium but is always tending to it (Mahadea \& Youngleson 2013; Urban 2008). Kirzner $(1997,2009)$ asserts that entrepreneurs are alert in spotting profitable opportunities unnoticed by others, and they harness the necessary resources to exploit those opportunities for business success. In the Schumpeterian framework, entrepreneurs are those creative individuals who envision an invention or develop an innovation in the form of a new production function, a new product or process and a combination of ideas to create a new business and expand that business successfully (Luiz 2008). Schumpeter's entrepreneurs are distinguished by their ability to create 'new combinations' beyond the current production function. Through this innovative process, inefficient firms are displaced, but this creative destruction process is ultimately beneficial and is the main force behind productivity gains and economic growth (Aghion \& Howitt 1992; Baumol 2011).

Shane (2003) argues that as an economy operates in a state of disequilibrium, entrepreneurship links opportunities to enterprising individuals. He adds that opportunities always exist in a society but lack an agency; hence human actions are necessary for the opportunities to be exploited by discerning entrepreneurs who recombine resources to create a new business and a new means-end framework for profit. By so doing, they enhance economic growth and bring about changes to the production frontier (Audretsch \& Keilbach 2011; Wennerkers \& Thurik 1999).

The production function model, expressing the relationship between economic output and inputs (capital, labour and technology), has dominated growth economics since Solow (1956). It is represented by the following equation:

$Y_{t}=F\left(K_{t}, L_{t}, A_{t}\right)$

[Eqn 1]

The neoclassical model suggests that aggregate output $\left(Y_{t}\right)$ is a function of capital $\left(K_{t}\right)$, labour $\left(L_{t}\right)$ and technology $\left(A_{t}\right)$, and all the variables are time dependent. An advancement in technological innovation makes a given amount of capital and labour more productive. Entrepreneurship is considered as part of the residual factor, entering the neoclassical model through the technology variable. Although technology is critical in the growth process, it remains exogenous in the Solow model.

As a response to the limitations of the Solow model, in the 1980s the endogenous growth models emerged (Mankiw 2014). Herein, economic growth arises through internal processes from within the system, such as the enhancement of a society's human capital (education and training), which in turn leads to new ideas, to research and development, new 
forms of technology and infrastructure, as well as the advancement of efficiency in production systems. These progressions are underpinned largely by the actions of entrepreneurs (Barro 2003; Grossman \& Helpman 1991; Romer 1990).

Economic growth and entrepreneurship can be viewed endogenously as a virtuous circle where innovations and economic advancement, in turn, create more entrepreneurial opportunities which generate incentives for potential entrepreneurs to become alert to them, thus creating wealth and leading to sustained economic growth. Parker (2009) asserts that a thriving economy provides greater scope for entrepreneurship expansion (opportunity entrepreneurship). On the other hand, high unemployment may push certain individuals to take the self-employment route to earn an income, out of necessity or desperation (necessity entrepreneurship). High unemployment may also reflect low economic growth and hence low entrepreneurial opportunities (Audretsch \& Keilbach 2011; Baumol 2009).

According to the occupational choice perspective, one becomes an entrepreneur if wage income from gainful employment is much less than the income benefits and other perks accruing from self-employment (Burton, Sorensen \& Dobrev 2016; Casson 2003). This study asserts that high unemployment in South Africa, low earnings from certain types of gainful employment and insecurity or poor career mobility prospects at the workplace, partly because of employment equity, drive many people to seek refuge in entrepreneurship by opening a small formal or informal business where start-up costs are low. This perspective might explain why there is an expanding informal sector in the South African economy. Stats SA has noted the unskilled workers as a group have the highest unemployment rates (SARB 2016).

On the other hand, the high wage structure in South Africa might encourage the majority of skilled and semi-skilled individuals to opt for secure gainful employment in the private and public sectors instead of delving into entrepreneurship, which is fraught with income uncertainties and risks (Lings 2014). This assertion is supported by the GEM Report (2015), which notes that entrepreneurial activity in South Africa is much lower than its emerging market peers.

Accordingly, this article assesses whether there is a link between income, entrepreneurship and unemployment, using dynamic ordinary least squares (DOLS) regression. In this regard, two hypotheses were tested, as indicated below. Income is proxied by real per capita GDP for the 1994-2015 period, and entrepreneurship by the TEA rate post-1994. Unemployment is measured according to the narrow official definition, taken as the percentage of the economically active population (aged 15-64) who were available to work and took active steps to seek employment during the preceding 2 weeks but did not succeed and hence did not work (Mohr 2016).

\section{Methodology}

Stemming from the literature discussed above, this article attempts to assess two hypotheses over the long run:

- an increase in unemployment in the South African economy leads to a rise in entrepreneurial activity

- a rise in national income creates opportunities for entrepreneurship development.

In order to test these hypotheses, this study adopts the following model specified by Plehn-Dujowich (2011) and Ghavidel, Farjadi and Mahammadpour (2011):

$E_{t}=\beta_{0}+\beta_{1} U_{t}+\beta_{2} Y_{t}+\varepsilon_{t}$

[Eqn 2]

where $E_{t}$ represents TEA entrepreneurship, measuring the proportion of working age population both about to start an entrepreneurial activity and those that have been engaged in one for at most 3.5 years, measured in percentages; $U_{t}$ represents the unemployment rate (unemployed relative to total working age population measured in percentages). The narrow definition of unemployment is used. $Y_{t}$ represents the natural $\log$ of real GDP at 2010 constant prices; $\varepsilon_{t}$ represents the error terms, which are assumed to be normally distributed with a zero mean and constant variance. Total entrepreneurship activity was obtained from the GEM reports and website, while data on the unemployment rate and real GDP were obtained from the South African Reserve Bank. All data were measured at a yearly frequency.

\section{Data issues}

Data on TEA in South Africa is available only from 2001. Accordingly, the TEA data for 1994-2000 had to be extrapolated. So, the study used simple but robust trend techniques to back-cast the TEA series to 1994 to increase the sample size for the purposes of regressing reasonable long-run relationships. The following trend regression was estimated using the 2001-2015 (15 observations) estimates of TEA:

$E_{t}=3.921667+0.214$ Trend
$t$-statistic $\quad(3.42) \quad(2.07)$

[Eqn 3]

It is to be noted that both coefficients were statistically significant at the $1 \%$ and $5 \%$ levels, respectively. The graph in Figure 3 depicts the complete (1994-2015) TEA dataset used in this study together with real per capita GDP. The first seven data points were generated using equation 3 . The extrapolated TEA thus ranged from $4.1 \%$ (1994) to $5.3 \%$ (2000). These points are considered to be plausible since the ushering of the democratic era unlocked business opportunities for all citizens in 'rainbow' South Africa. Both the per capita GDP income and TEA series show an upward trend over the period under consideration (Figure 3). The 15 data points (2001-2015) used to derive equation 3 show a positive trend, which justifies its use in extrapolating the earlier seven points. 


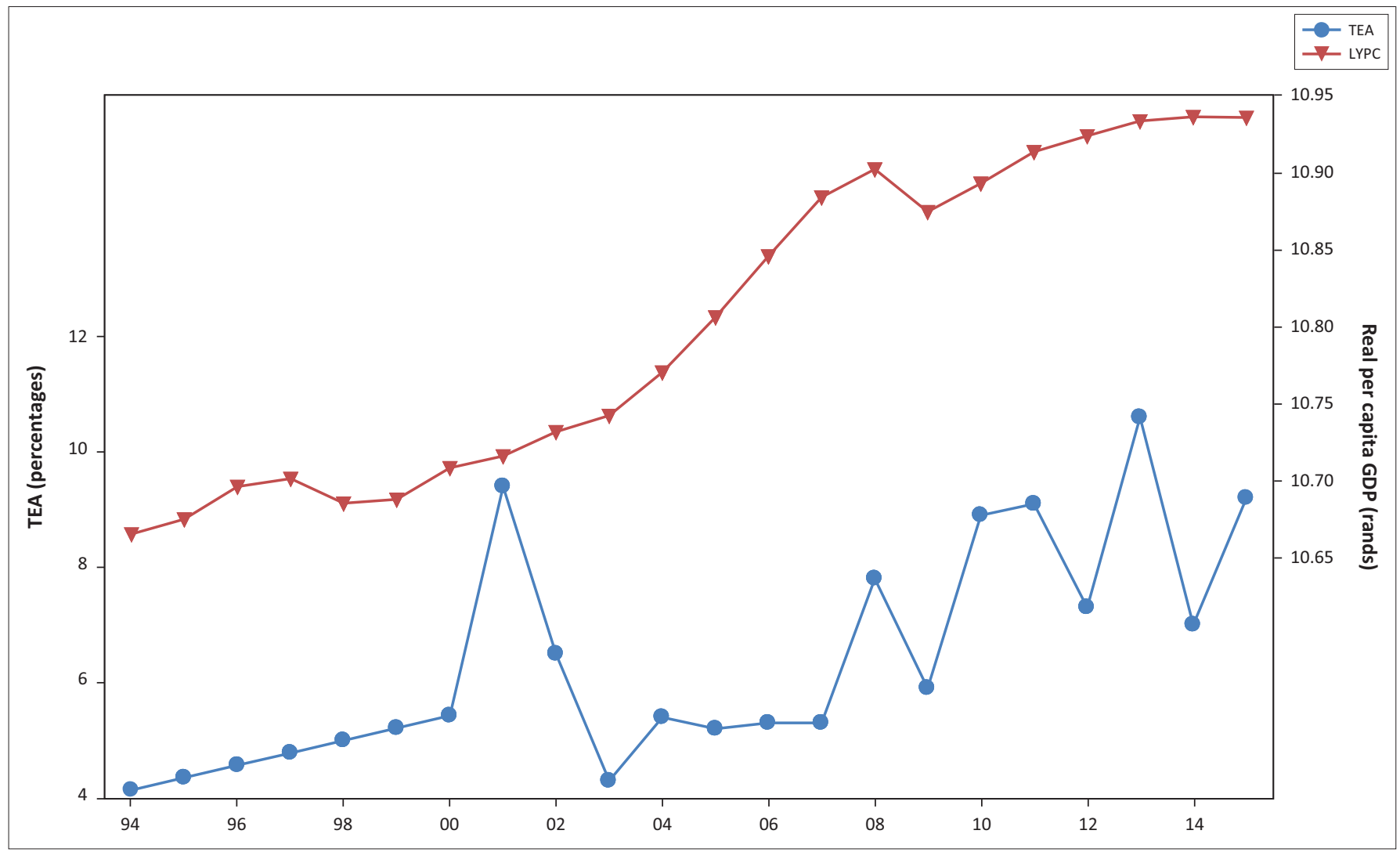

FIGURE 3: Graph of total entrepreneurship activity and real per capita gross domestic product.

TABLE 1: Unit root tests.

\begin{tabular}{lcclcc}
\hline Variable & \multicolumn{2}{c}{ Levels } & & \multicolumn{2}{c}{ First difference } \\
\cline { 2 - 3 } \cline { 5 - 6 } & Tau statistic & Critical value & & Tau statistic & Critical value \\
\hline TEA & -1.93 & $-4.43(1 \%)$ & & -7.57 & $-4.50(1 \%)$ \\
Real per capita GDP & -2.13 & $-4.98(1 \%)$ & & -2.19 & $-1.96(5 \%)$ \\
Unemployment & -2.02 & $-3.79(1 \%)$ & & -51.8 & $-3.81(1 \%)$ \\
\hline
\end{tabular}

Note: All bracketed percentages indicate significance level of the critical statistic.

Trend and intercept were used to estimate the levels tau statistic for TEA and real per capita GDP series, while only intercept was used for the unemployment one; GDP, gross domestic product; TEA, total entrepreneurship activity.

\section{Statistical modelling procedure}

Since this article deals with an extremely small dataset (21 observations), the Stock and Watson (1993) DOLS modelling technique was chosen as a preferred procedure. Monte Carlo simulations have shown that the DOLS estimator generates superior results, in small samples, compared to alternative approaches (e.g. Johansen VAR 1991 and fully modified ordinary least squares [OLS] of Phillips \& Hansen 1990). This article estimates the long-run relationship as expressed in equation 2, which in the Stock and Watson (1993) DOLS form: $B=\left[\beta_{0}, \beta_{1}, \beta_{2}\right], X=\left[1, U_{t}, Y_{t}\right]$, where $B$ and $X$ are the long-run coefficient and variable vectors, respectively, which enter into the following DOLS specification:

$$
E_{t}=B^{\prime} X_{t}+\sum_{j=-J}^{j=J} \gamma_{j} \Delta U_{t-j}+\sum_{j=-k}^{j=k} \lambda_{j} \Delta Y_{t-k}+\xi_{t}
$$

This DOLS specification enables the study to estimate the long-run parameters through regressing any I(1) variables on other I(1) variables, any I(0) variables and leads and lags of the first differences of any I(1) variables. However, since the sample size is a constraint, only one lead and lag of a variable was selected.

\section{Presentation and discussion of results}

As this study seeks to establish a long-run association between the variables, it is critical to avoid the possibility of spurious regressions. Hence, the augmented Dickey Fuller (ADF) unit roots tests were first conducted to ensure that all variables entering the regression are integrated of the same order [i.e. I(1)], commonly known as 'nonstationary variables'. This is a standard practice in time series econometrics since unrelated variables entering a regression may lead to valid regression results due to common trends in the data, despite there being no economic reason for such relationships. However, in justified long-run economic relationships, regressions involving $\mathrm{I}(1)$ variables will generate residuals that tend to be stationary [i.e. I(0)]; such variables are said to be cointegrated in the sense they exhibit a sensible dynamic co-movement over time.

Table 1 reports the ADF unit root tests. These confirm that all the series entering the regression were $\mathrm{I}(1)$; since in levels the tau calculated statistics for all three series $(-1.93,-2.13,-2.02)$ are greater than the tau critical at $1 \%$ significance, upon first differencing the tau statistic in all cases $(-7.57,-2.19,-51.8)$ are less than their corresponding tau critical values at conventional significance levels. 
TABLE 2: Dynamic ordinary least squares regression results - Dependent variable: Total entrepreneurship activity.

\begin{tabular}{lccccccc}
\hline Variables & Coefficient & $\boldsymbol{R}^{2}$ & Standard error of regression & Standard error & $\boldsymbol{t}$-Statistic & Sum of squared residuals & Long-run variance \\
\hline Constant & -175.5 & 0.665 & 1.454 & 32.447 & $-5.41 * * *$ & 21.315 \\
Log Real per capita GDP & 16.30 & - & - & 2.9714 & $5.48 * * *$ & - \\
Unemployment rate & 0.24 & - & - & 0.1350 & $1.77 *$ & - \\
\hline
\end{tabular}

Note: Adjusted sample was from 1996 to 2014 , where 19 observations were included after adjustments, fixed lead and lag specification (lead = 1, lag = 1). The long-run variance estimate (Bartlett kernel, Newey-West fixed band width $=30000$ ).

$* * *, * *$ and $*$ represent $1 \%, 5 \%$ and $10 \%$ significance levels.

GDP, gross domestic product.

\begin{tabular}{llc} 
TABLE 3: Cointegration tests. & & \\
\hline Test & Value & Probability \\
\hline Engle Granger cointegration test: & & \\
$\quad$ Engle Granger tau statistic & -4.073 & 0.059 \\
$\quad$ Engle Granger Z-statistic & -19.302 & 0.043 \\
Phillips-Ouliaris cointegration test: & & \\
$\quad$ Phillips-Ouliaris tau statistic & -4.196 & 0.048 \\
$\quad$ Phillips-Ouliaris Z-statistic & -20.231 & 0.031 \\
\hline
\end{tabular}

Since all the variables were integrated of the same order, entering them in the DOLS regression in their levels form was justified. Table 2 presents the results of the DOLS regression.

The DOLS regression results show that both the natural log of real per capita GDP $(b=16.30)$ and the unemployment rate $(b=0.24)$ have a positive and statistically significant causal effect on TEA (Table 2). The coefficient associated with real per capita GDP suggests that a $1 \%$ rise in per capita GDP results in a $0.163 \%$ rise in TEA, perhaps reflecting opportunity entrepreneurship. The coefficient associated with the unemployment rate indicates that a $1 \%$ rise in unemployment results in a $0.24 \%$ rise in TEA. This may reflect a measure of displacement or necessity entrepreneurship, as unemployed individuals are forced to seek refuge by starting up a business, because they have no alternative employment opportunities or no other means to gain income. The entrepreneurship elasticity of unemployment, though significant, is rather low and inelastic, possibly reflecting a lack of relevant skills and resources for venturing into self-employment among the unemployed.

The results of Table 2 convincingly - especially when considered in conjunction with the confirmation of cointegration in Table 3 - demonstrate that a valid long relationship between the variables does exist that is consistent with economic reasoning. The interpretation of the slope coefficients suggests that output growth is a critical factor that explains the rise in entrepreneurial activity in the South African economy. As the theory asserts, a growing economy creates opportunities for new firms to emerge, existing businesses to expand, for new enterprises displacing outdated ones and entirely new innovative concerns taking root, producing hitherto unknown goods and services. As individuals and economies develop, they accumulate income and wealth through economic growth, which promote further entrepreneurship (Herrington and Kew, 2016). The weak impact of unemployment on TEA suggests that in an economy with low growth, employment opportunities are limited. Hence, some unemployed individuals by necessity seek refuge as a last resort by venturing into the self-employment route. However, this may not necessarily reflect as high a level of entrepreneurial activity as opportunity entrepreneurship.

The long-run relationship presented in Table 3 is plausible, especially since the Engle Granger tau and Z-statistics confirm that the variables are cointegrated with the respective $p$-values of 0.59 and 0.043 . Moreover, these results are corroborated by the Phillips-Ouliaris cointegration tests, where the tau and Z-statistics are significant with the $p$-values of 0.048 and 0.031 , respectively (Table 3 ).

Overall, since cointegration is confirmed, the regression coefficients are statistically significant, and the diagnostic tests discussed below indicate that the DOLS model is a robust one. This implies that the estimated regression possesses strong predictive value for the South African economy, consistent with those found for the USA and Pakistan by Plehn-Dujowich (2011) and Ghavidel et al. (2011), respectively.

\section{Diagnostic tests}

The study considered the diagnostic tests for normality of residuals, serial correlation and heteroscedasticity, which are reported in the appendix. The Jarque-Bera statistic reported in Figure 1-A1 of the appendix is about 1.04, and the probability of obtaining such a statistic under the normality assumption is 59.4\%; thus one does not reject the null hypothesis that the residuals are normally distributed.

The Q-statistics and their corresponding $p$-values for the correlogram of the 12 lags of the residuals depicted in Figure 2-A1 of the appendix demonstrates that serial correlation is not a problem.

Figure 3-A1 of the appendix shows the Breusch-PaganGodfrey heteroscedasticity test results, demonstrating that the null hypothesis of homoscedasticity should be accepted since the probability of obtaining the $F$-statistic, $\mathrm{n} \times \mathrm{R}^{2}$ and the scaled explained sum of squares (ESS) statistics are high at $59.96 \%, 56.2 \%$ and $52.51 \%$, respectively.

In light of all the diagnostic tests as well as the cointegration tests, one may conclude that the study has generated a credible model to explain the impact of per capita income and unemployment on entrepreneurial activity. However, it should also be pointed out that the limited data on TEA is perhaps a limitation of the study. However, this was overcome by the extrapolation method. Nevertheless, the results are sufficiently robust, pointing to a policy guidance of a strong 
long-run relationship between unemployment, income and entrepreneurship in South Africa.

Accordingly, there is support for the two hypotheses formulated earlier. If more employment and entrepreneurial capabilities are to be created, it is critical to have an economy that exhibits high growth rates which in turn generates growth in real per capita income. This is consistent with the NDP's suggestion that South Africa needs higher levels of SME entrepreneurship and economic growth rates to reduce unemployment and inequality. If entrepreneurial capacity, especially among the unemployed youth, can be enhanced, more individuals can be their own job creators by venturing into self-employment and expanding small businesses, rather than be job-seekers as salaried labour. Evidently, this entails that the constraints that inhibit business entrepreneurship be identified and addressed.

\section{Study limitations and future directions}

In its quest to examine cointegrating relationships between TEA, per capita GDP and unemployment, the study was forced to use a small available data set, as TEA data on South Africa have only been available since 2001. Due to the statistical need of maintaining maximum degrees of freedom when running regression models, it was not possible to include control variables. Furthermore, the study only focused on South Africa. Hence, future studies might include other emerging economies in a panel data framework. This will also allow control variables, such as structural reforms, ease of doing business index, political stability and levels of corruption, to mention a few, to be examined and how these generate comparative dynamic relations between economic or income growth, (un)employment and entrepreneurship over time.

\section{Policy suggestions and conclusion}

The South African economy is not growing fast enough to absorb the rising annual number of job-seekers. The rising unemployment is likely to push individuals, especially the youth, into entrepreneurship out of necessity to earn an income to survive. However, their aspirations should not be foiled by a hostile regulatory environment.

As the results of the present study indicate, the entrepreneurship elasticity of unemployment is rather low, only $0.24 \%$, though significant. This might be a reflection that the unemployed have few requisite skills. They may suffer from serious constraints to make a rational entry into entrepreneurship. Banking institutions might not be prepared to offer assistance to such high-risk cases.

A related concern to entrepreneurial activity is the quality of the workforce and poor levels of education and training (Herrington 2012; Lings 2014). The 2014 GEM clearly indicates that a strong correlation exists between perceived skills of individuals of all participating countries and TEA.
According to the World Economic Forum's (WEF) Global Competitiveness Report 2015/2016, South Africa ranks rather low on quality of education (120th out of 140 countries), making it difficult to generate the required type of skills needed for a competitive economy. The education system in South Africa is devastating because it is limiting (Mashaba 2015). Acquisition of a high level of human capital is thus necessary for South Africa to move from its present 'low growth equilibrium' level to a higher platform of entrepreneurship (FNB 2010; Herrington 2012; Parsons 2013).

It is no surprise that only $10.9 \%$ of individuals in South Africa have entrepreneurial intentions, although about $74 \%$ regard entrepreneurship as a good career (Kelly et al. 2016). This low entrepreneurial propensity among certain groups could also arise because of their fear of failure. The corporate or public sector employment then becomes a more attractive and less risky job option. Enhancing the quality of education and training can make labour more employable and attract more people of ability to become entrepreneurs (Chen \& Thompson 2016). Government ought to adopt technical skills development programmes among the unemployed to improve their selfconfidence and prospects of entering into self-employment.

On the other hand, as indicated by the GEM and World Economic Forum (WEF) reports, environmental factors relating to South Africa's entrepreneurial ecosystem are perceived to be unfriendly. These include high levels of corruption, government regulations and red tape, crimes and violence, poor quality education and levels of productivity, labour market rigidities and adverse labour relations (Herrington 2012; Parsons 2013). All these augment transaction costs and impose heavy burdens on competitiveness as well as making entrepreneurship less attractive. This is also evidenced by the World Bank's Doing Business Report for 2016, which saw South Africa ranked 73rd globally, down five places since 2015. Thus, unless a propitious environment is created to address these constraints, our growth potential will remain low, entrepreneurship will not flourish fully and the growing number of jobless youth and unemployed individuals in South Africa will have little hope of realising their income and employment aspirations.

Increases in real per capita GDP income are found, in the present study, to have a highly significant influence on enhancing entrepreneurship. The prospects of real growth in GDP income and poverty alleviation or job creation are weak in a stagnant economy. Income increases with economic growth and provides greater scope for entrepreneurship and employment; a $1 \%$ increase in GDP per capita income is found to be associated with a $0.16 \%$ rise in early stage entrepreneurship. Income growth thus has a positive scale effect on enhancing the scope of entrepreneurship. Given the strong relationship between GDP and entrepreneurship, the foundation for an entrepreneurial economy needs to be strengthened in South Africa. This will call for pragmatic and prudent macroeconomic policies which include low inflation, incentives for entrepreneurs, contained government 
spending, the provision of infrastructure, addressing corruption and political risks and uncertainties.

\section{Acknowledgements}

The authors would like to extend their thanks to the managing editor of this journal and to the reviewers for their feedback and assistance on this article.

\section{Competing interests}

The authors declare that they have no financial or personal relationships that may have inappropriately influenced them in writing this article.

\section{Authors' contributions}

The conceptualisation of the article was done by D.M. and the statistical part was done by I K. Both contributed to the writing of the article.

\section{References}

Aghion, P. \& Howitt, P., 1992, 'A model of growth through creative destruction', Econometrica 60, 323-351. https://doi.org/10.2307/2951599

Audretsch, D.B. \& Keilbach, M., 2011, 'Knowledge Spillover Entrepreneurship, innovation and economic growth', in D.B. Audretsch, O. Falck, S. Heblich \& A. Lederer (eds.), Handbook of research on innovation and entrepreneurship, pp. 245-272, Edward Elgar, Cheltenham, UK.

Barro, R.J., 2003, 'Determinants of economic growth in a panel of countries', Annals of Economics and Finance 4(2), 231-274.

Baumol, W.J., 2009, The microtheory of innovative entrepreneurship, Princeton University Press, Princeton, NJ.

Baumol, W.J., 2011, 'Invention and social entrepreneurship: Social good and social evil', in D.B. Audretsch, O. Falck, S. Heblich \& A. Lederer (eds.), Handbook of research on innovation and entrepreneurship, pp. 3-11, Edward Elgars, research on innov
Cheltenham, UK.

Burton, M., Sorensen, J. \& Dobrev, S., 2016, 'A careers perspective on entrepreneurship', Entrepreneurship Theory and Practice 40(2), 237-248. https://doi.org/10.1111/ etap.12230

Casson, M., 2003, The entrepreneur: An economic theory, Edward Elgar, Aldershot.

Chen, L. \& Thompson, P., 2016, 'Skill balance and entrepreneurship', Entrepreneurship Theory and Practice 40(2), 289-306. https://doi.org/10.1111/etap.12220

De Meza, D. \& Webb, C., 1987, 'Too much investment: A problem of asymmetric information', Quarterly Journal of Economics 102, 281-292. https://doi.org/ $10.2307 / 1885064$

FNB, 2010, The state of entrepreneurship in South Africa, FNB, Johannesburg.

Ghavidel, S., Farjadi, G. \& Mahammadpour, A., 2011, 'The relationship between entrepreneurship and unemployment in developed and developing countries', in International Conference on Applied Economics, ICOAE, August 25-27, Perugia, Italy, pp. 189-192.

Grossman, G.M. \& Helpman, E., 1991, 'Growth and welfare in a small open economy', in E. Helpman \& A. Razin (eds.), International trade and trade policy, pp. 141-163, MIT Press, Cambridge, MA.

Herbst, J. \& Gills, G., 2015, How South Africa works, Macmillan, Johannesburg. Herrington, M., 2012, 'African entrepreneurship lacking!', Business Brief 17(5), 14.
Herrington, M. \& Kew, P., 2016, Global Entrepreneurship Monitor- South African Report 2015/16: Is South Africa heading for an economic meltdown? Development Unit for New Enterprise, UCT, Cape Town.

Herrington, M., Kew, J. \& Kew, P., 2015, 2014 GEM report SA: The crossroads A goldmine or a time bomb? DUNE, Western Cape Government, Cape Town.

Johansen, S., 1991, 'Estimation and hypothesis testing of cointegration vectors in Gaussian Vector autoregressive models', Econometrica 59(6), 1551-1580. https:// doi.org/10.2307/2938278

Johnson, H.W., 2015, How long will South Africa survive? Jonathan Ball Publishers, Cape Town.

Kantor, B., 2017, Get South Africa Growing, Jonathan Ball, Johannesburg.

Kelly, D., Singer, S. \& Herrington, M., 2016, GEM 2015/16 Global Entrepreneurship Monitor, South African Report, GSB, University of Cape Town, Cape Town.

Kerr, A., Wittenberg, M. \& Arrow, J., 2014, 'Job creation and destruction in South Africa', South African Journal of Economics 82(1), 1-19. https://doi.org/10.1111/ saje.12031

Kirzner, I.M., 1997, 'Entrepreneurial discovery and the competitive market process: An Austrian approach', Journal of Economic Literature 35(1), 60-85.

Kirzner, I.M., 2009, 'The alert and creative entrepreneur: A classification', Small Business Economics 32(2), 145-152. https://doi.org/10.1007/s11187-008-9153-7

Kritikos, A.S., 2014, 'Entrepreneurship and their impact on jobs and economic growth', IZA World of Labour 8, 1-10.

Lings, K., 2014, The missing piece: Solving South Africa's economic puzzle, Macmillan, Johannesburg.

Luiz, J.M., 2008, 'Economic perspectives of entrepreneurship', in B. Urban (ed.), Frontiers in entrepreneurship, pp. 63-84, Heinemann, Johannesburg.

Mahadea, D. \& Youngleson, J., 2013, Entrepreneurship and small business management, Pearson, Cape Town

Mankiw, G., 2014, Macroeconomics, Harvard, Worth Publishers, New York.

Mashaba, H., 2015, The capitalist crusader: Fighting poverty through economic growth, Bookstorm, Johannesburg.

Mohr, P., 2016, Economic indicators, Van Schaik, Braamfontein

Naude, W., 2008, 'Entrepreneurship in the field of development economics', in B. Urban (ed.), Frontiers in entrepreneurship, pp. 85-114, Heinemann, Johannesburg.

Nieman, G. \& Nieuwenhuizen, C., 2014, Entrepreneurship: A South African perspective, 3rd edn., Van Schaik, Pretoria.

OECD, 2017, Getting skills right: South Africa, OECD Publishing, Paris. https://doi. org/10.1787/9789264278745-en

Parker, S.C., 2009, The economics of entrepreneurship, Cambridge University Press, Cambridge, UK.

Parsons, R., 2013, Zumanomics, Jacana, Johannesburg.

Phillips, P.C.B. \& Hansen, B.E., 1990, 'Statistical inference in instrumental variables regression with I(1) processes', Review of Economics Studies 57, 99-125. https:// doi.org/10.2307/2297545

Romer, P.M., 1990, 'Endogenous technological change', Journal of Political Economy 98, 71-102. https://doi.org/10.1086/261725

SARB, 2015, South African Reserve Bank Quarterly Bulletin, SARB, Pretoria, p. 277.

SARB, 2016, South African Reserve Bank Quarterly Bulletin, SARB, Pretoria, p. 280.

Shane, S., 2003, A general theory of entrepreneurship, Edward Elgar, Northampton, MA.

Solow, R.M., 1956, 'A contribution to the theory of economic growth', Quarterly Journal of Economics 70, 65-94. https://doi.org/10.2307/1884513

Stock, J. \& Watson, M.W., 1993, 'A simple estimator of cointegration vectors in higher order integrated systems', Econometrica 61(4), 783-820. https://doi.org/ $10.2307 / 2951763$

Urban, B., 2008, Frontiers in entrepreneurship, B. Urban (ed.), Heinemann, Johannesburg.

Urban, B., 2013, 'Influence of the institutional environment on entrepreneurial intentions in an emerging economy', The International Journal of Entrepreneurship and Innovation 14(3), 179-192. https://doi.org/10.5367/ijei.2013.0122

Wennerkers, S. \& Thurik, R., 1999, 'Linking entrepreneurship and economic growth', Small Business Economics 13(1), 27-55. https://doi.org/10.1023/A:1008063200484 


\section{Appendix 1}

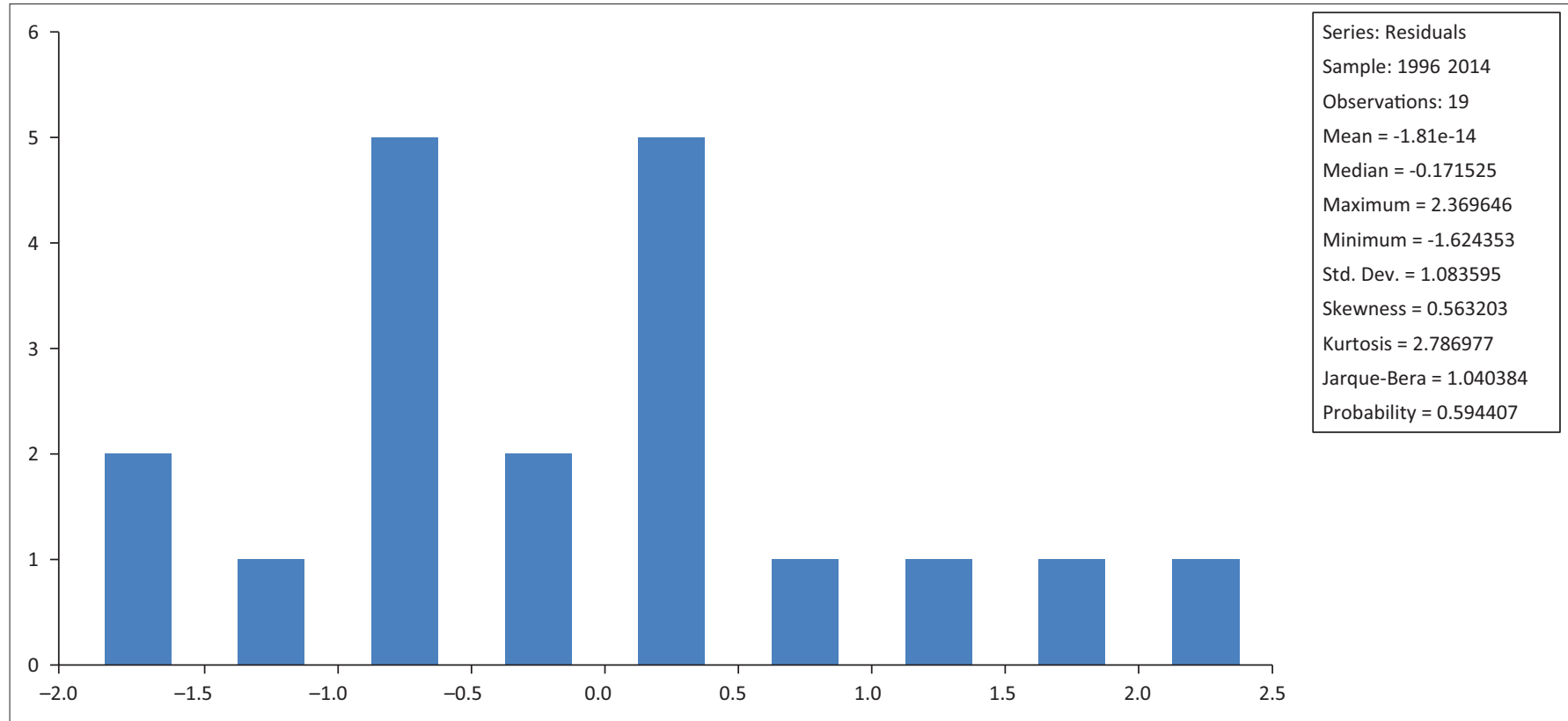

FIGURE 1-A1: Jarque-Bera normality test.

\begin{tabular}{|c|c|c|c|c|c|c|}
\hline \multicolumn{7}{|c|}{\begin{tabular}{|l|} 
Sample: $1994-2015$ \\
Included observations: 19
\end{tabular}} \\
\hline Autocorrelation & \multicolumn{2}{|c|}{ Partial correlation } & \multirow{2}{*}{\begin{tabular}{|l|} 
AC \\
-0.430
\end{tabular}} & \multirow{2}{*}{$\begin{array}{l}\text { PAC } \\
-0.430\end{array}$} & \multirow{2}{*}{\begin{tabular}{|l|} 
Q-Stat \\
4.0959 \\
\end{tabular}} & \multirow{2}{*}{$\begin{array}{l}\text { Prob* } \\
0.043\end{array}$} \\
\hline ***|. $\mid$ & $* * *$ & 1 & & & & \\
\hline .1 .1 &.$^{* * 1}$ & 2 & -0.042 & -0.279 & 4.1381 & 0.126 \\
\hline $.1^{*}$. & .1 . & 3 & 0.118 & -0.033 & 4.4867 & 0.213 \\
\hline$.{ }^{*} \mid$. & ${ }^{*} \mid$ & 4 & -0.189 & -0.200 & 5.4386 & 0.245 \\
\hline .1 .1 & ${ }^{*} \mid$ & 5 & 0.054 & -0.143 & 5.5208 & 0.356 \\
\hline.${ }^{*}||$. &.$* * 1$ & 6 & -0.089 & -0.253 & 5.7637 & 0.450 \\
\hline .1 .1 & ${ }^{*} \mid$ & 7 & 0.060 & -0.144 & 5.8827 & 0.554 \\
\hline .1 .1 &.$^{* * 1}$ & 8 & -0.043 & -0.220 & 5.9502 & 0.653 \\
\hline .1 .1 &.$* *$ & 9 & -0.039 & -0.285 & 6.0112 & 0.739 \\
\hline$. .^{*} . \mid$ &.$^{* *}$ & 10 & 0.127 & -0.208 & 6.7319 & 0.750 \\
\hline.${ }^{*}||$. &.$* *$ & 11 & -0.102 & -0.332 & 7.2514 & 0.778 \\
\hline $.1^{* *} . \mid$ & .1. & 12 & 0.270 & 0.028 & 11.421 & 0.493 \\
\hline
\end{tabular}

AC, autocorrelation; PAC, partial autocorrelation; Q, Stat-Ljung-Box Q statistic for correlation in residuals; Prob, probability statistics.

*, Probabilities may not be valid for this equation specification.

FIGURE 2-A1: Correlogram: serial correlation test.

\begin{tabular}{|c|c|c|c|}
\hline \multicolumn{2}{|l|}{$F$-statistic $=0.526$} & \multicolumn{2}{|c|}{ Probability $F(2.19)=0.5996$} \\
\hline \multicolumn{2}{|c|}{ Observations $\times R^{2}=1.533$} & \multicolumn{2}{|c|}{ Probability chi-square $(2)=0.5618$} \\
\hline \multicolumn{2}{|c|}{ Scaled explained sum of squares $=1.288$} & \multicolumn{2}{|c|}{ Probability chi-square $(2)=0.5251$} \\
\hline \multicolumn{4}{|c|}{ Auxiliary regression to derive the Breusch-Pagan-Godfrey test statistics } \\
\hline \multicolumn{4}{|c|}{ Dependent variable: residuals squared } \\
\hline Variables & Coefficient & Standard error & $t$-statistic \\
\hline Constant & -18.06 & 84.23 & -0.21 \\
\hline Log Real per capita GDP & 1.27 & 7.89 & 0.16 \\
\hline Unemployment rate & 0.26 & 0.27 & 0.96 \\
\hline \multicolumn{2}{|c|}{$\begin{array}{l}R^{2}=0.052 \\
\text { Standard error of regression }=3.646 \\
\text { Sum of squared residuals }=252.64 \\
\text { Log likelihood }=-58.07 \\
\text { Probability }(F \text {-statistic })=0.5996\end{array}$} & \multicolumn{2}{|c|}{$\begin{array}{l}\text { Durbin-Watson statistic }=2.51 \\
\text { Akaike info criterion }=5.55 \\
\text { Schwarz criterion }=5.70 \\
\text { Hannan-Quinn criterion }=5.59\end{array}$} \\
\hline
\end{tabular}

GDP, gross domestic product.

FIGURE 3-A1: Breusch-Pagan-Godfrey heteroscedasticity test. 